\title{
The Attitudes of Jordanians toward Using Sms English: A Descriptive Study
}

\author{
May Shikhali (Corresponding author) \\ Department of English language and Translation \\ Amman Arab University, Jordan \\ Abad Alaziz Jumah Al Fawareh \\ Department of English language and Translation \\ Amman Arab University, Jordan \\ Khaleel Bader Al Bataineh \\ Department of English language and Translation \\ Amman Arab University, Jordan
}

Received: September 9, 2020 Accepted: September 30, 2020 Published: October 5, 2020

doi:10.5296/ijele.v8i2.17787 URL: https://doi.org/10.5296/ijele.v8i2.17787

\begin{abstract}
The study aimed to investigate the attitude of 36 participants on using Sms in their conversation and writing. To achieve the study objectives, a questionnaire was developed and reliability and validity of the questionnaire were checked. The study sample consisted of 36 using Sms. twelve of them were parents. The results of the study indicated that each of the three groups use Sms differently. Sms English is used for communication by the majority as it saves time, space and easy to use. Finally, in light of the results, future studies should analyze the use of Sms English with respect to other participants. Research undertaking a bigger sample should be done to arrive at a more concrete conclusion.
\end{abstract}

Keywords: Sms English, English language, communication, Jordan 


\section{Introduction}

Sms English is the latest version of English. It is mainly used when electronic media is involved in communication such as when chatting online, sending e-mails or smses. It is also known as webspeak, chatspeak, txt, txtspeak, texting language or txt talk. It is actually a written variation of Standard English. Hence, it differs from Standard English on account of spellings and grammar. The words used in this language, can't be found in standard dictionaries. It evolved as a result of invention of new modes of communication - mobile phones, personal computers and internet. These modes of communication require people to type words instead of writing. As a result, people, who are totally unaccustomed to typing, are forced to find a new alternative to express their thoughts and ideas in a faster manner. Martinet (1900) says that linguistic evolution may be regarded as governed by the permanent conflict between man's communicative needs and his tendency to reduce to a minimum, his mental and physical activity. A linguistic evolvement occurred in English Language, too. Sms English evolved. Since writing modes have changed, only writing features of Standard English are altered as per demand and time. The spellings are made more phonetic; articles, prepositions are omitted; punctuation marks are omitted or stripped to bare necessities. Over a period of time, the number of variations increased and became large enough to form a separate and individual variation of English language.

However, this is not for the first time that English language has undergone change. "Language, like everything else, joins in this general flux. As the German philosopher-linguist Wilhelm von Humboldt noted in 1836: "there can never be a moment of true standstill in language, just as little as in the ceaseless flaming thought of men. By nature, it's a continuous process of development." (Aitchson, 2001, p.3) Swiss linguist Ferdinand de Saussure says, that time changes all things. There is no reason why language should escape this universal law.

Large number of educators condemns and resent language change, regarding alterations as due to unnecessary sloppiness, laziness or ignorance. A study conducted by Geertsema et al. (2011) stated that sms English has a negative effect on the written language skills. Another study by Winzker et al. (2009) indicated that sms English have a great influence on student's writing performance. Likewise, Shaari \& Bataineh (2015) stated that online language hinders the entire process of English language acquisition and learning. With the enormous exposure to online language, EFL students may believe this as something normal or perhaps confusing. It is vital to make these students conscious that Sms language is not yet appropriate in an official writing convention.

The researchers have attempted to record the attitudes of a small group of people, toward the variation in English language occurring in the form of Sms English, through this research paper. Thus, this research carried out to achieve the following objectives: a) to investigate Jordanian students' attitudes toward the use of English Sms. and b) to investigate Jordanian teachers and patents' attitudes toward using Sms English. This research tried to answer the following research questions: 1 . What are the attitudes of Jordanian students toward the use of English Sms? 2. What are the attitudes of Jordanian teachers and parents toward the use of 
English Sms?

\section{Methodology}

\subsection{Research Design}

This is a non-experimental research using a survey-based questionnaire to examine the attitude of the participants toward Sms English. This research is a quantitative descriptive design.

\subsection{Participants and Instrumentation}

Random selection from a group of people whose medium of education is English or Semi-English. A questionnaire containing 15 questions was given to all the 36 participants at Amman Arab University. The questions were the same for the participants. The participants were informed that the questionnaire dealt with Sms English. They were then asked to fill the questionnaire. The questionnaires, thus collected, then were analyzed.

Table 1. Distribution of the Participants

\begin{tabular}{|l|c|}
\hline Category & Number of Participants \\
\hline Students & 24 \\
\hline Parents & 6 \\
\hline Teachers & 6 \\
\hline
\end{tabular}

\subsection{Validity and Reliability}

The questionnaire's face validity was checked by all the lecturers at the Department of English Language and Translation at Amman Arab University. The researchers amended the questionnaire according to their comments.

For the sake of the reliability, a pilot of study was conducted on five students from outside the sample of the study. After gathering and analyzing students' responses, the Pearson correlation coefficient was 0.83 , which is satisfactory for the targets of the present research.

\subsection{Data Analysis}

The data was collected from participants in summer 2020, during the summer semester. The questionnaire was administrated by the researchers and a brief induction as well as aims of the study was provided to the students. The gathered data was analyzed accordingly. The Analysis of the questionnaires is presented in tabular form. The 15 questions in the questionnaire, for easy reference, have been divided into 2 groups:

a) Questions which are informative (Q. Nos. - 1, 2, 3, 4, 5, 8, 10 and 11).

b) Questions which demand personal response (Q. Nos. - 6, 7, 9, 12, 13, 14 and 15). 
The participants for easy reference are given codes. They are as follows:

Table 2. Codes of the participants

\begin{tabular}{|l|l|}
\hline Category & Code \\
\hline Student & S1 \\
\hline Student & S2 \\
\hline Student & S3 \\
\hline Student & S4 \\
\hline Student & S5 \\
\hline Student & S6 to S24 \\
\hline Parent & P1 \\
\hline Parent & P2 \\
\hline Parent & P3 to P6 \\
\hline Teacher & T1 \\
\hline Teacher & T2 \\
\hline Teacher & T3 toT6 \\
\hline
\end{tabular}

\section{Finding and Discussion}

\section{RQ 1: What are the attitudes of Jordanian students toward the use of English Sms?}

To answer the research question, the 24 students' questionnaires have been analyzed and tabulated in the following tables.

Table 3. Informative questions

\begin{tabular}{|l|l|l|l|l|l|l|l|l|}
\hline Q. Nos. & 1 & 2 & 3 & 4 & 5 & 8 & 10 & 11 \\
\hline $\begin{array}{l}\text { Gist of } \\
\text { Qs. }\end{array}$ & $\begin{array}{l}\text { sends } \\
\text { sms }\end{array}$ & $\begin{array}{l}\text { sends } \\
\text { e-mails }\end{array}$ & Chats & $\begin{array}{l}\text { lang. } \\
\text { used }\end{array}$ & $\begin{array}{l}\text { similar or } \\
\text { different }\end{array}$ & rules & $\begin{array}{l}\text { uses } \\
\text { elsewhere }\end{array}$ & $\begin{array}{l}\text { negative } \\
\text { effects }\end{array}$ \\
\hline S1 & Yes & Yes & Yes & Sms & Similar & No & No & No \\
\hline S2 & Yes & Yes & Yes & Sms & Different & No & Yes & Yes \\
\hline S3 & Yes & Yes & Yes & Sms & Different & No & No & Yes \\
\hline S4 & Yes & Yes & Yes & Sms & Different & Yes & Yes & Yes \\
\hline S5 & Yes & Rarely & No & Sms & Different & No & No & Yes \\
\hline S6 & Yes & Yes & Yes & Sms & Different & Yes & No & No \\
\hline S7 & Yes & Yes & Yes & Sms & Similar & No & No & No \\
\hline S8 & Yes & Yes & Yes & Sms & Different & No & Yes & Yes \\
\hline S9 & Yes & Yes & Yes & Sms & Different & No & No & Yes \\
\hline
\end{tabular}




\begin{tabular}{|l|l|l|l|l|l|l|l|l|}
\hline S10 & Yes & Yes & Yes & Sms & Different & Yes & Yes & Yes \\
\hline S11 & Yes & Rarely & No & Sms & Different & No & No & Yes \\
\hline S12 & Yes & Yes & Yes & Sms & Different & Yes & No & No \\
\hline S13 & Yes & Yes & Yes & Sms & Similar & No & No & No \\
\hline S14 & Yes & Yes & Yes & Sms & Different & No & Yes & Yes \\
\hline S15 & Yes & Yes & Yes & Sms & Different & No & No & Yes \\
\hline S16 & Yes & Yes & Yes & Sms & Different & Yes & Yes & Yes \\
\hline S17 & Yes & Rarely & No & Sms & Different & No & No & Yes \\
\hline S18 & Yes & Yes & Yes & Sms & Different & Yes & No & No \\
\hline S19 & Yes & Yes & Yes & Sms & Similar & No & No & No \\
\hline S20 & Yes & Yes & Yes & Sms & Different & No & Yes & Yes \\
\hline S21 & Yes & Yes & Yes & Sms & Different & No & No & Yes \\
\hline S22 & Yes & Yes & Yes & Sms & Different & Yes & Yes & Yes \\
\hline S23 & Yes & Rarely & No & Sms & Different & No & No & Yes \\
\hline S24 & Yes & Yes & Yes & Sms & Different & Yes & No & No \\
\hline
\end{tabular}

Table 4. Personal response questions

\begin{tabular}{|c|c|c|c|c|c|c|c|}
\hline $\begin{array}{l}\text { Q. } \\
\text { Nos. }\end{array}$ & 6 & 7 & 9 & 12 & 13 & 14 & 15 \\
\hline $\begin{array}{l}\text { Gist } \\
\text { of Qs }\end{array}$ & $\begin{array}{lr}\text { Why } & \text { Sms } \\
\text { Lang. } & \text { is } \\
\text { used } & \end{array}$ & easy & encourage & $\begin{array}{l}\text { Future of Sms } \\
\text { Eng. }\end{array}$ & $\begin{array}{l}\text { Which is } \\
\text { better }\end{array}$ & $\begin{array}{l}\text { Toward } \\
\text { progress or } \\
\text { decay }\end{array}$ & $\begin{array}{l}\text { Preferred } \\
\text { lang. }\end{array}$ \\
\hline $\mathrm{S} 1$ & Saves time & Yes & Yes & $\begin{array}{l}\text { Only Sms will } \\
\text { be used }\end{array}$ & Equal & Neither & Sms. \\
\hline $\mathrm{S} 2$ & $\begin{array}{l}\text { Saves time } \\
\text { and is easy }\end{array}$ & Yes & Both & $\begin{array}{l}\text { Usage will } \\
\text { increase }\end{array}$ & $\begin{array}{l}\text { Both have } \\
\text { goods and } \\
\text { bads }\end{array}$ & Decay & Sms. \\
\hline S3 & $\begin{array}{lr}\begin{array}{l}\text { Easy, } \\
\text { time }\end{array} \text { and } \\
\text { space }\end{array}$ & Yes & Yes & Will progress & Sms & $\begin{array}{l}\text { Progress as } \\
\text { well decay }\end{array}$ & Sms \\
\hline S4 & $\begin{array}{l}\text { Saves time } \\
\text { and is 'cool' }\end{array}$ & Yes & Yes & Bright future & Cant compare & Decay & Sms \\
\hline S5 & $\begin{array}{lr}\text { To } & \text { avoid } \\
\text { space } & \text { and } \\
\text { time } & \end{array}$ & Yes & No & $\begin{array}{l}\text { Not so good, } \\
\text { not so bad }\end{array}$ & Standard & Decay & $\begin{array}{l}\text { Standard } \\
\text { English }\end{array}$ \\
\hline S6 & $\begin{array}{l}\text { Saves typing } \\
\text { efforts }\end{array}$ & Yes & No & $\begin{array}{l}\text { If formalized } \\
\text { then bad }\end{array}$ & Standard & Decay & $\begin{array}{l}\text { Standard } \\
\text { English }\end{array}$ \\
\hline S7 & Saves time & Yes & Yes & $\begin{array}{l}\text { Only Sms will } \\
\text { be used }\end{array}$ & Equal & Neither & Sms. \\
\hline S8 & Saves time & Yes & Both & Usage will & Both & Decay & Sms. \\
\hline
\end{tabular}




\begin{tabular}{|c|c|c|c|c|c|c|c|}
\hline & and is easy & & & increase & $\begin{array}{l}\text { goods and } \\
\text { bads }\end{array}$ & & \\
\hline S9 & $\begin{array}{l}\text { Easy, Saves } \\
\text { time and } \\
\text { space }\end{array}$ & Yes & Yes & Will progress & Sms & $\begin{array}{l}\text { Progress as } \\
\text { well decay }\end{array}$ & Sms \\
\hline S10 & $\begin{array}{l}\text { Saves time } \\
\text { and is 'cool' }\end{array}$ & Yes & Yes & Bright future & $\begin{array}{l}\text { Can't } \\
\text { compare }\end{array}$ & Decay & Sms \\
\hline S11 & $\begin{array}{lr}\text { To avoid } \\
\text { space and } \\
\text { time }\end{array}$ & Yes & No & $\begin{array}{l}\text { Not so good, } \\
\text { not so bad }\end{array}$ & Standard & Decay & $\begin{array}{l}\text { Standard } \\
\text { English }\end{array}$ \\
\hline $\mathrm{S} 12$ & $\begin{array}{l}\text { Saves typing } \\
\text { efforts }\end{array}$ & Yes & No & $\begin{array}{l}\text { If formalized } \\
\text { then bad }\end{array}$ & Standard & Decay & $\begin{array}{l}\text { Standard } \\
\text { English }\end{array}$ \\
\hline S13 & Saves time & Yes & Yes & $\begin{array}{l}\text { Only Sms will } \\
\text { be used }\end{array}$ & Equal & Neither & Sms. \\
\hline S14 & $\begin{array}{l}\text { Saves time } \\
\text { and is easy }\end{array}$ & Yes & Both & $\begin{array}{l}\text { Usage will } \\
\text { increase }\end{array}$ & $\begin{array}{l}\text { Both have } \\
\text { goods and } \\
\text { bads }\end{array}$ & Decay & Sms. \\
\hline S15 & $\begin{array}{l}\text { Easy, Saves } \\
\text { time and } \\
\text { space }\end{array}$ & Yes & Yes & Will progress & Sms & $\begin{array}{l}\text { Progress as } \\
\text { well decay }\end{array}$ & Sms \\
\hline S16 & $\begin{array}{l}\text { Saves time } \\
\text { and is 'cool' }\end{array}$ & Yes & Yes & Bright future & $\begin{array}{l}\text { Can't } \\
\text { compare }\end{array}$ & Decay & Sms \\
\hline S17 & $\begin{array}{lr}\text { To avoid } \\
\text { space and } \\
\text { time }\end{array}$ & Yes & No & $\begin{array}{l}\text { Not so good, } \\
\text { not so bad }\end{array}$ & Standard & Decay & $\begin{array}{l}\text { Standard } \\
\text { English }\end{array}$ \\
\hline S18 & $\begin{array}{l}\text { Saves typing } \\
\text { efforts }\end{array}$ & Yes & No & $\begin{array}{l}\text { If formalized } \\
\text { then bad }\end{array}$ & Standard & Decay & $\begin{array}{l}\text { Standard } \\
\text { English }\end{array}$ \\
\hline S19 & Saves time & Yes & Yes & $\begin{array}{l}\text { Only Sms will } \\
\text { be used }\end{array}$ & Equal & Neither & Sms. \\
\hline S20 & $\begin{array}{l}\text { Saves time } \\
\text { and is easy }\end{array}$ & Yes & Both & $\begin{array}{l}\text { Usage will } \\
\text { increase }\end{array}$ & $\begin{array}{l}\text { Both } \\
\text { goods } \\
\text { bads }\end{array}$ & Decay & Sms. \\
\hline $\mathrm{S} 21$ & $\begin{array}{l}\text { Easy, } \\
\text { time } \\
\text { space }\end{array}$ & Yes & Yes & Will progress & Sms & $\begin{array}{l}\text { Progress as } \\
\text { well decay }\end{array}$ & Sms \\
\hline S22 & $\begin{array}{l}\text { Saves time } \\
\text { and is 'cool' }\end{array}$ & Yes & Yes & Bright future & $\begin{array}{l}\text { Can't } \\
\text { compare }\end{array}$ & Decay & Sms \\
\hline S23 & $\begin{array}{lr}\text { To avoid } \\
\text { space and } \\
\text { time }\end{array}$ & Yes & No & $\begin{array}{l}\text { Not so good, } \\
\text { not so bad }\end{array}$ & Standard & Decay & $\begin{array}{l}\text { Standard } \\
\text { English }\end{array}$ \\
\hline $\mathrm{S} 24$ & $\begin{array}{l}\text { Saves typing } \\
\text { efforts }\end{array}$ & Yes & No & $\begin{array}{l}\text { If formalized } \\
\text { then bad }\end{array}$ & Standard & Decay & $\begin{array}{l}\text { Standard } \\
\text { English }\end{array}$ \\
\hline
\end{tabular}


As retrieved from the above results, it can be clearly seen that all the participants send sms and emails while 20 students chat on daily basis. All the students use Sms English while doing the above three activities. 20 students feel Sms English is different from Standard English while 1 student feels it is similar. The reasons given by the 20 students to support their answer are that Sms English uses short forms of words and does not follow grammatical rules. The interesting thing is that the student who says Sms English is similar, too, gives the same reason that Sms English uses short forms of Standard English.

16 students say no rules are followed in using Sms English. 4 student mention only one rule is followed, which state that only those words are to be shortened which are of routine use. Only 4 students specify rules like omitting vowels and prepositions etc. but at the same time say the rules are not rigid. 16 students do not use Sms English anywhere else, other than sending smses, e-mails or chatting. 4 students use Sms English in school notebooks while the other student uses it in personal diary and cards. In addition, 8 students do not feel any negative impact on their Standard English because of the use of Sms English. 8 students, who do not use Sms English elsewhere; along with 8 students, who use Sms English elsewhere; feel their Standard English is negatively affected. They become habituated to using Sms English and hence, use it instead of Standard English. They forget Standard English in a hurry.

All the students say that Sms English is used as it saves time. Some students also add that it saves space, is easy, and saves typing efforts. 4 students say it is also a 'cool' statement to use Sms English as it is the 'happening' thing. All the students agree Sms English is easy to learn and understand. 3 students say it becomes easy with usage; while 2 students say it is only short forms and hence is easy. 12 students encourage others to use Sms English because it saves time and space and is easy. 4 students don't care. 4 students feel it affects Standard English negatively. I student is confused as Sms English, on one hand is easy and time saving; on the other hand it is hazardous if over used.

Moreover, 16 students feel that Sms English has bright future and will spread while 8 students see future of Sms English is dark, if Sms English is used formally. 8 students have said Standard English is better as it is proper and enables expressing easy and better. 12 students feel both the languages cannot be compared as they serve different purposes. Only 4 students feel that Sms English is better as it saves time, space and is easy. 16 students feel Sms English is taking English toward decay because it affects Standard English negatively (in terms of grammar, vocabulary, spellings) and the authenticity of the language is lost.4 students feel Sms English is abuse of language; though he does use it.4 students feels Sms English is taking English toward progress as it is easy, fast and saves space, but it is also taking English toward decay as it is not improving English. 4 students feel it is nothing but fun. Though almost 20 students feel Sms English is decaying English; 16 students, if are given a choice, would like to use Sms English. Their reasons are- its easiness; time and space saving characteristics. 4 students, who choose to use Standard English, if choice is given, will do so as it has large vocabulary and is original. 
RQ 2: What are the attitudes of Jordanian teachers and parents toward the use of English Sms?

To answer this research question, the 6 Parents and 6 Teachers' questionnaires have been analyzed and tabulated in the following tables.

Table 5. Informative Questions

\begin{tabular}{|c|c|c|c|c|c|c|c|c|}
\hline Q. Nos. & 1 & 2 & 3 & 4 & 5 & 8 & 10 & 11 \\
\hline $\begin{array}{l}\text { Gist of } \\
\text { Qs. }\end{array}$ & $\begin{array}{l}\text { sends } \\
\text { sms }\end{array}$ & $\begin{array}{l}\text { sends } \\
\text { e-mails }\end{array}$ & Chats & $\begin{array}{l}\text { lang. } \\
\text { used }\end{array}$ & $\begin{array}{ll}\text { similar } & \text { or } \\
\text { different } & \end{array}$ & rules & $\begin{array}{l}\text { uses } \\
\text { elsewhere }\end{array}$ & $\begin{array}{l}\text { negative } \\
\text { effects }\end{array}$ \\
\hline $\mathrm{P} 1$ & Yes & Yes & No & Sms & Different & No & No & No \\
\hline $\mathrm{P} 2$ & Yes & No & No & Both & Different & No & No & No \\
\hline P3 & Yes & No & No & Sms & Different & No & No & No \\
\hline P4 & Yes & Yes & No & Sms & Different & No & No & No \\
\hline P5 & Yes & No & No & Both & Different & No & No & No \\
\hline P6 & Yes & No & No & Sms & Different & NO & No & No \\
\hline $\mathrm{T} 1$ & Yes & Yes & No & Std. & Different & No & Yes & Yes \\
\hline $\mathrm{T} 2$ & Yes & Yes & Yes & Std. & Different & No & No & No \\
\hline $\mathrm{T} 3$ & Yes & Yes & No & Std. & Different & No & No & Yes \\
\hline $\mathrm{T} 4$ & Yes & Yes & No & Std. & Different & No & Yes & Yes \\
\hline $\mathrm{T} 5$ & Yes & Yes & Yes & Std. & Different & No & No & No \\
\hline T6 & Yes & Yes & No & Std. & Different & No & No & Yes \\
\hline
\end{tabular}

Table 6. Personal Response

\begin{tabular}{|c|c|c|c|c|c|c|c|}
\hline $\begin{array}{l}\text { Q. } \\
\text { Nos. }\end{array}$ & 6 & 7 & 9 & 12 & 13 & 14 & 15 \\
\hline $\begin{array}{l}\text { Gist } \\
\text { of Qs }\end{array}$ & $\begin{array}{l}\text { Why Sms } \\
\text { Lang. is } \\
\text { used }\end{array}$ & easy & Encourage & $\begin{array}{l}\text { Future of Sms } \\
\text { Eng. }\end{array}$ & $\begin{array}{l}\text { Which is } \\
\text { better }\end{array}$ & $\begin{array}{l}\text { Toward } \\
\text { progress or } \\
\text { decay }\end{array}$ & $\begin{array}{l}\text { Preferred } \\
\text { lang. }\end{array}$ \\
\hline P1 & $\begin{array}{l}\text { Saves } \\
\text { time }\end{array}$ & Yes & Not really & $\begin{array}{l}\text { Fast way to } \\
\text { communicate }\end{array}$ & $\begin{array}{l}\text { Cant } \\
\text { compare }\end{array}$ & Both differ & Both \\
\hline $\mathrm{P} 2$ & $\begin{array}{l}\text { Short } \\
\text { and fast }\end{array}$ & Yes & Yes & $\begin{array}{l}\text { Will become a } \\
\text { part of English }\end{array}$ & Both & Decay & Both \\
\hline P3 & $\begin{array}{l}\text { Saves } \\
\text { time }\end{array}$ & Neither & No & $\begin{array}{l}\text { Standard short } \\
\text { forms may evolve }\end{array}$ & $\begin{array}{lr}\text { Sms } & \text { Eng. } \\
\text { only } & \text { for } \\
\text { smses } & \end{array}$ & Decay & Sms \\
\hline P4 & $\begin{array}{l}\text { Saves } \\
\text { time }\end{array}$ & Yes & Not really & $\begin{array}{l}\text { Fast way to } \\
\text { communicate }\end{array}$ & $\begin{array}{l}\text { Can't } \\
\text { compare }\end{array}$ & Both differ & Both \\
\hline P5 & Short & Yes & Yes & Will become & Both & Decay & Both \\
\hline
\end{tabular}




\begin{tabular}{|c|c|c|c|c|c|c|c|}
\hline & and fast & & & part of English & & & \\
\hline P6 & $\begin{array}{l}\text { Saves } \\
\text { time }\end{array}$ & Neither & No & $\begin{array}{l}\text { Standard short } \\
\text { forms may evolve }\end{array}$ & $\begin{array}{l}\text { Sms Eng. } \\
\text { only for } \\
\text { smses }\end{array}$ & Decay & Sms \\
\hline $\mathrm{T} 1$ & $\begin{array}{l}\text { Short; } \\
\text { saves } \\
\text { time }\end{array}$ & Yes & Yes & Shall develop & $\begin{array}{l}\text { Sms better, } \\
\text { if it } \\
\text { develops }\end{array}$ & Progress & Sms \\
\hline $\mathrm{T} 2$ & $\begin{array}{l}\text { Saves } \\
\text { time }\end{array}$ & Yes & Yes & $\begin{array}{l}\text { Mixing may } \\
\text { result }\end{array}$ & None & Decay & $\begin{array}{l}\text { Standard } \\
\text { English }\end{array}$ \\
\hline $\mathrm{T} 3$ & $\begin{array}{l}\text { Saves } \\
\text { time }\end{array}$ & No & No & Shall be used & Standard & Decay & $\begin{array}{l}\text { Standard } \\
\text { English }\end{array}$ \\
\hline $\mathrm{T} 4$ & $\begin{array}{l}\text { Short; } \\
\text { saves } \\
\text { time }\end{array}$ & Yes & Yes & Shall develop & $\begin{array}{l}\text { Sms better, } \\
\text { if it } \\
\text { develops }\end{array}$ & Progress & Sms \\
\hline $\mathrm{T} 5$ & $\begin{array}{l}\text { Saves } \\
\text { time }\end{array}$ & Yes & Yes & $\begin{array}{l}\text { Mixing may } \\
\text { result }\end{array}$ & None & Decay & $\begin{array}{l}\text { Standard } \\
\text { English }\end{array}$ \\
\hline T6 & $\begin{array}{l}\text { Saves } \\
\text { time }\end{array}$ & No & No & Shall be used & Standard & Decay & $\begin{array}{l}\text { Standard } \\
\text { English }\end{array}$ \\
\hline
\end{tabular}

As retrieved from the above results, it can be clearly seen that all the participants (parents and teachers) send smses while 8 participants send e-mails and 2 participants chat on daily basis. 6 participants use Standard English while doing the above three activities, 4 participants use Sms English while 2 participants use both. All the participants feel Sms English is different from Standard English. The reason given by all of them to support their answer is that Sms English uses short forms of words. However, all the participants say no rules are followed in using Sms English, but 2 participants add that the only rule to be followed is using short forms.

In addition, 10 participants do not use Sms English anywhere else, other than sending smses, e-mails or chatting. 2 participants use Sms English in instructing his subordinates. Also, 8 participants do not feel any negative impact on their Standard English because of the use of Sms English while 2 participants, who do not use Sms English elsewhere; along with 2 participants, who use Sms English elsewhere; feel their Standard English is negatively affected. They become habituated to using Sms English and also the meaning is unclear.

All the participants say that Sms English is used as it saves time. Some participants also add that it is short. 8 participants say Sms English is easy to learn and understand. 2 participants say it is neither easy nor difficult; while 2 participants say it is hard as it lacks clarity. 6 participants encourage others to use Sms English because it saves time and is easy and simple. 4 participants say difficulties arise because of too many short forms. 2 participants suggest that short, simple but complete sentences should be used.

6 participants feel that Sms English will evolve and becomes a part of or will mix into Standard English. 2 participants see development of Sms English as it requires little efforts to 
use. 4 participants feel it will be used for convenience like communication in future. 4 participants feel Sms English is not better as it is just a new version created by man. 2 participants feel comparing is not fair as both are different purposes. 4 participants differentiate both languages as per their uses. Sms English is better for communication while Standard English is better for other purposes. 2 participants are confident that Sms English will become better, in future, after it has developed further.

Thus, 4 participants feel Sms English is taking English toward decay because it is or might replace Standard English. Also, it affects Standard English negatively (in terms of grammar, vocabulary, spellings). 2 participants feel Sms English is taking English toward progress as it does away with complexities and confusion. 2 students feel both are different. 4 participants, if given a choice, would like to use Sms English as it saves time, energy and unnecessary thinking. 4 participants prefer to segregate both the languages for different purposes. Sms English is their choice only for communication. 4 participants, who choose to use Standard English, if choice is given, will do so as it is understood by all and Sms English is abuse of English language.

\subsection{Overall Findings}

Sms English is used by all the students of the study. This shows that Sms English is widely used. This is due to the tremendous technological development and the spread of smart devices among Jordanians (Al Bataineh et al., 2001). Moreover, it is used because it saves time, space and is short and easy. It is used only for communication purposes by 36 participants while 9 participants also use it for instruction, making notes, and writing diary. 18 participants encourage others to use Sms English because it is time saving, simple and easy. 18 participants would prefer to use Sms English if a free-reign is given to choose a language, while 6 participants would prefer using Sms English only for communication and Standard English for all other purposes and 12 participants would prefer to use Standard English.

Sms English, as per 30 participants, follows no rules while other 6 participants specify the rules as shortening of routine words by cutting vowels, etc. Sms English is different from Standard English on account of its variation in written form. Sms English negatively affects 18 participants' usage of Standard English.

Sms English is better, as per 39 participants. It is taking English toward progress, as per 3 participants only and toward decay, as per 24 participants. As per 15 participants Sms English in future will spread and develop; as per 9 participants, it will replace or mix with or become a part of Standard English and as per 6 participants, it will remain as means of communication. The results of this study concurs with Aljaraideh and Al Bataineh (2019), Shaari \& Bataineh (2015), Njemanze, (2012), Ping, A. C. et al (2011), Geertsema et al. (2011), Winzker et al. (2009), O'connor (2006)

\subsection{Limitation of the Study}

The current research is limited to the 36 participants of the study at a private university in Jordan. Only questionnaire was used in this descriptive study. The results reflect the attitudes 
of 36 participants and it is based on a small sample to truly capture the general attitude of people. Research undertaking a bigger sample should be done to arrive at a more concrete conclusion.

\section{Conclusion}

Sms English is widely used. It is used because it saves time, space and is short and easy. It is used only mostly for communication purposes. People at times do encourage others to use Sms English because it is time saving, simple and easy. 50\% people would prefer to use Sms English if a free-reign is given to choose a language, while around $20 \%$ people would prefer using Sms English only for communication and Standard English for all other purposes and $30 \%$ people would prefer to use Standard English.

Sms English follows no rules except the rule of shortening of words and sentences. Sms English is different from Standard English on account of its variation in written form. Sms English negatively affects many persons' usage of Standard English. Very few people feel Sms English is better. Most of the people feel Sms English is taking English toward decay. It is loosing syntax, vocabulary and spelling system. Sms English in future will spread and develop; it might also replace or mix with or become a part of Standard English or at least it will remain as means of communication is what all people believe.

Though most of the people believe Sms English is taking English toward decay and that Sms English is not better than Standard English, they are also confident that Sms English is such a variation in English language which has occurred to stay. Their belief in strong future of Sms English is strengthened by more and more usage of Sms English in Advertising world, Tabloids and Digital Art forms such as Digital Poetry.

People's attitude to Sms English is very complex. On one hand, they use the variation in the language on a larger scale and know its practical beneficiary points; and hence, are even receptive to the idea of Sms English assuming greater role in English language, in future. Yet on the other hand, they feel it is decaying of English language and hence, look down upon it from aesthetic ground.

\section{References}

Aitchson, Jean. (2001). Language Change: Progress or Decay? (3 ${ }^{\text {rd }}$ ed.). Cambridge University Press, Cambridge.

Aljaraideh, Y., \& Al Bataineh, K. (2019). Jordanian Students' Barriers of Utilizing Online Learning: A Survey Study. International Education Studies, 12(5), 99-108. https://doi.org/10.5539/ies.v12n5p99

Bataineh, K. B., Atoum, M. S., Alsmadi, L. A., \& Shikhali, M. (2020). A Silver Lining of Coronavirus: Jordanian Universities Turn to Distance Education. International Journal of Information and Communication Technology Education (IJICTE), 17(2), 1-11. 
https://doi.org/10.4018/IJICTE.20210401.oa1 2020, Vol. 8, No. 2

Geertsema, S., Hyman, C., \& Van Deventer, C. (2011). Short message service (SMS) language and written language skills: educators' perspectives. South African Journal of Education, 31(4), 475-487. https://doi.org/10.15700/saje.v31n4a370

Gorden J. Mathew. (2002). Investing Chain Shifts And Mergers; In Chambers, Trudgill, and Schilling-Estes; The Handbook of Language Variation and Change, Blackwell Publishers.

Njemanze, Q. U. (2012). The SMS Style of Communication: Implications of Language Usage Among Nigerian University Students' Communication. Journal of Communication, 3(1), 17-23.

O Conner. (2005). Instant Messaging: Friend or Foe of Students ${ }^{e e}$ Writing? New Horizon for Learning. [Online] available: http: www.newhorizon.org/ strategies/ literacy, o conner, htm (May 28, 2011).

Ping, A. C. et al. (2011). The Impact of SMS on Writing: A Case Study Among University Students in Klang Valley. SEGi Reviw, 4(2), 109-124.

Shaari, A. H., \& Bataineh, K. B. (2015). Netspeak and a Breach of Formality: Informalization and Fossilization of Errors in Writing among ESL and EFL Learners. International Journal for Cross-Disciplinary Subjects in Education (IJCDSE), 6(2).

Winzker, K., Southwood, F., \& Huddlestone, K. (2009). Investigating the impact of SMS speak on the written work of English first language and English second language high school learners. Per Linguam: a Journal of Language Learning= Per Linguam: Tydskrif vir Taalaanleer, 25(2), 1-16.

www.wikipedia.com, $20^{\text {th }}$ dec, 2007; 22hours.

\section{Copyright Disclaimer}

Copyright for this article is retained by the author(s), with first publication rights granted to the journal.

This is an open-access article distributed under the terms and conditions of the Creative Commons Attribution license (http://creativecommons.org/licenses/by/3.0/). 